\title{
LEGAL FORM, COVID AND THE POLITICAL: NOTES TOWARDS A CRITIQUE OF THE CORPUS IURIS PANDEMICI ${ }^{1}$
}

\begin{abstract}
The scholarly analysis and critique of law always take place under circumstances of scarcity of academic resources. At any given moment, the number of academic jurists mastering a given legal system and being capable of analysing and critiquing it at a professional scientific level is limited. The pandemic of COVID-19 only exacerbated this phenomenon, exposing the importance of making methodological and paradigmatic choices. What critical legal theory teaches us is that the choice of method and approach to the analysis and critique of legal materials is not politically neutral. Asking about the political goals and choices behind solutions adopted by legislators, ministers, civil servants, law enforcement officers, and judges, and about the actual interests impacted by their decisions is much more important and topical in these difficult times. A sociologically oriented critical legal theory can provide the necessary tools for such an analysis of the corpus iuris pandemici.
\end{abstract}

Keywords: legal form, COVID-19, the political, critical legal theory.

\section{FORMA PRAWNA, COVID I POLITYCZNOŚĆ: PRZYCZYNEK DO KRYTYKI CORPUS IURIS PANDEMICI}

Streszczenie. Akademicka analiza i krytyka prawa zawsze odbywa się w warunkach niedostatku zasobów. W danym momencie liczba prawników-akademików, którzy znają dany system prawny i są w stanie go analizować i poddawać krytyce na profesjonalnym poziomie naukowym jest ograniczona. Pandemia COVID-19 jedynie pogłębiła to zjawisko, uwypuklając znaczenie dokonywanych wyborów dotyczących metody i paradygmatu badań. Krytyczna teoria prawa wskazuje, że wybór metody i podejścia do analizy i krytyki materiałów prawnych nie jest neutralny politycznie. Pytanie o polityczne cele i wybory stojące za rozwiązaniami przyjmowanymi przez ustawodawców, ministrów, urzędników państwowych, funkcjonariuszy organów ścigania i sędziów, a także o rzeczywiste interesy, na które wpływają ich decyzje, jest niezwykle aktualne $\mathrm{w}$ tych trudnych czasach. Socjologicznie zorientowana krytyczna teoria prawa może dostarczyć niezbędnych do tego narzędzi do prowadzenia tego rodzaju badań nad corpus iuris pandemici.

Słowa kluczowe: forma prawna, COVID-19, polityczność, krytyczna teoria prawa.

${ }^{*}$ University of Amsterdam \& Nomos International Centre for the Study of Law, Power and Culture; r.t.manko@uva.nl. All views expressed in this paper are purely personal and do not present the position of any institution.

${ }^{1}$ I would like to thank Dr Przemysław Tacik for his comments on this paper, and the two anonymous peer reviewers for their valuable feedback. 


\section{INTRODUCTION}

As I am writing these words in mid-April 2021, our species has entered its second year of coping with the COVID-19 pandemic, considered as "the greatest threat to global public health of the century [but also] ... as an indicator of inequity and deficiency of social advancement" (Šimanskienè, Paužuolienė, Staškevičius 2020, 95). The law - understood here simply (but provisionally) as a set of general and abstract rules enacted and enforced by the state - has played a significant role in the response towards the threat posed by the virus. States of emergency, lockdowns, travel bans, social distancing measures, social bubbles, prohibitions of public gatherings, and more recently procurement contracts for vaccines and priority lists of social groups queuing for vaccination: all these forms of social engagement with the pandemic are, at least in our part of the world (the 'Global North'), deeply juridified. But the intensive use of law to tackle the pandemic has put the legal form as such under stress. Ministerial press conferences, official websites on COVID measures, or simply local policing practices have increasingly become sources - at least iuris cognoscendi if not downright iuris oriundi - of what can be dubbed as the emergent "corpus iuris pandemici.". Weeks or months later courts are striking back, annulling measures as illegal or unconstitutional, reducing penalties as disproportionate, releasing people from detention or, to the contrary, confirming administrative penalties and sentencing to deprivation of liberty for violation of measures. A distinct feature of these times is the sudden and strong re-emergence of national law: the corpus iuris pandemici is a distinctly national (or, in federal states, even regional) corpus, it exists in almost splendid isolation in each and every country (or federised state), mirroring the re-emergence of the strong nation-state as the main actor in tackling the pandemic and contributing to the fragmentation of our legal life. Borders have suddenly re-emerged where they were absent, and existing ones were insulated in an unprecedented manner (Lara Ortiz 2020).

As legal literature on the pandemic is emerging and the question is gaining more and more interest not only from doctrinal researchers in public law, but also from legal theorists and socio-legal scholars, my aim is to put forward a number of preliminary research questions which seem relevant from the standpoint of critical legal theory. I aim to indicate, in outline, what kind of aspects of the corpus iuris pandemici could inform a "critical jurisprudence of the pandemic," so to say. My aim is not to provide answers, but rather to provide an intellectual framework for a critical engagement with the corpus iuris pandemici by indicating what tools critical legal theory can provide to the pandemic and what aspects of that corpus can be elucidated fruitfully using those tools.

${ }^{2}$ The term is, of course, a neo-Latinism, created from the English adjective 'pandemic' (Latinicized to pandemicus). Given the importance of Latin for European culture, we cannot afford to leave it to the ancients. 
The paper will first address (in section 2) the question of social agonism and the corpus iuris pandemici by pointing to five distinct socio-legal practices which can and should be interrogated from the perspective of an agonistic theory of law: constitutionalism; legislation; regulation; administrative action; adjudication. In a second part, the paper will address two horizontal issues: legal form and the pandemic (section 3), on one hand, and legal ideology and the pandemic (section 4), before concluding (section 5).

\section{CORPUS IURIS PANDEMICI AND THE POLITICAL}

One of the fundamental assumptions of critical legal theory is the presence of an agonism in every society, i.e. the conflictual nature of social life and the fact that this conflictual (agonistic) dimension is reflected in socio-legal practices (Mańko, Łakomy 2018, 475-477; cf. Mouffe 2013). Whereas the presence of conflicts is rather obvious in the case of adjudication (where the clash of interests of plaintiffs and defendants is plainly visible), conventional jurisprudence is prone to prioritising order and harmony when speaking about constitutionalism, legislation, or even regulation and administrative action (Mańko 2020d, 31-32). However, even in the case of adjudication critical legal theory goes beyond what the conventional legal theorist is prepared to accept, namely by extrapolating the individual conflicts of interests (plaintiff vs. defendant) towards collective conflicts which constitute the juridical reflection of economic and ideological conflicts nurturing any society (Kennedy 1997; Mańko 2021). The most obvious ones are class conflicts, reflected within the juridical in the guise of three typical antagonisms: worker v. employer; tenant v. landlord; consumer v. trader (Mańko 2020c; Mańko 2020d). Even if there can be rich tenants and consumers, and poor employers and landlords, the typicality of the legal relationship (in the sense of ideal type, but also statistical prevalence) is what counts from the perspective of an agonistic perspective on the law. These structural conflicts can be played out within the different strata of sociolegal practices: constitutionalism (the adoption, interpretation and application of the constitution, including through the use of constitutional states of emergency or the refusal to use them); legislation (the adoption of acts of parliament and decrees of a general nature); regulation (the adoption of detailed rules by government and executive agencies); administrative action (the adoption of individual decisions by public bodies, as well as the entire universe of coercive action, not necessarily taking strictly juridical forms, but expected to remain within the realm of law - think especially of policing in its various shapes and kinds); and finally adjudication (the business of courts, comprising the judicial interpretation and application of law and regulation, but also judicial review of legislation, regulation and administrative action, and the fact of judicial law-making which inevitably permeates the aforementioned practices). 
The pandemic has opened entirely new fronts of analysis of the five sociolegal practices, outlined above, in the light of the agonistic paradigm. The task of the critical jurist is, therefore, to analyse such phenomena as the use of states of emergency, the adoption of COVID legislation and regulation, COVID policing and COVID case-law through the lens of the social agonism, i.e. asking each time the question: cui prodest? Who is the beneficiary, as a collective group, of the deployment of a state of emergency, or of the refusal to deploy it? Who benefits from certain new COVID rules adopted in the guise of legislation or regulation? Whose interests are being protected by courts, and whose by the administration? All these questions have to be answered through a proper sociological analysis of the occurring processes, both in a large scale (e.g. nation-wide) and on the basis of individualised case-studies. The key to evaluating legislation, regulation, adjudication etc. is the search for alternatives (Mańko 2021, [15]). If a state of exception were declared, one should immediately ask the question what if it were not declared? If it were not declared, the opposing question what if it were declared ought to be asked. In the case of legislation, one should evaluate the choices made against all constitutionally possible alternatives. Idem for regulation, administrative action, and adjudication. The search for alternatives and the focus on the interest of collective groups is the key to a thoroughly critical methodology. Comparative pandemic law can be a powerful tool, providing the necessary counter-examples concerning all possible aspects of the corpus iuris pandemici - how did other countries deal with the manner on a constitutional level (state of emergency, emergency decrees vs. standard procedures), within legislation, regulation, etc. (cf. Mercescu 2019).

Let me illustrate these discussions with some concrete examples. For instance, the Polish pandemic regulation in force at the time of writing (mid-April 2021) provides that non-food shops of a surface above 1000 sq.m. need to be closed, whereas such shops under 1000 sq.m. may remain open. Furthermore, shopping malls are in principle closed, save for food shops, pet shops, and press shops. In contrast, the Belgian regulation at the same time provides that all non-food shops, whatever their size, may be open, but may be visited only upon earlier reservation. In practice, smaller electronic and clothing shops in Poland, if located outside shopping malls, remain open and are freely accessible, which is in contrast to the situation in Belgium. A properly critical approach will enquire cui prodest both types of regulation. Prima facie it seems that the Polish regulation favours privately held, smaller shops, which will tend to be owned locally, but this would obviously need to be verified e.g., on the basis of economic data. On the other hand, the Belgian rules seem to hit all types of non-food shops equally, though in practice it would remain to be seen which types of shops better cope with the reservation requirement.

To take another example, the Central European countries, during the first wave of the pandemic decided to close their borders for all incoming persons 
(save for own nationals and permanent residents) whereas the Western European countries initially kept their borders open. Today, during the third wave of the pandemic, the approach seems to be different, with the West of Europe closing its borders more stringently than the Centre of the continent. A properly critical approach should examine the actual beneficiaries and victims of both types of approaches, based at least on anecdotal evidence and case studies. An abstract, dogmatic approach to COVID legislation and regulation will not be capable of revealing anything in terms of the agonistic dimension of the corpus iuris pandemici.

A third example is the most topical one at the time of writing (mid-April 2021) as it is concerned with the rollout of vaccination programmes in various countries. The organisation of priority groups lends itself most clearly to an analysis in terms of the social antagonism. Whereas the prioritisation of medical personnel seems to be a common approach, other aspects remain rather different. For instance, in Poland prosecutors, psychologists, academic and school teachers have been included in one of the priority groups (1C) whereas in other countries such persons would be vaccinated only according to their age group. The Polish choice clearly reflects a preference towards safeguarding not only the medical service, but also the intellectual elite of the country (the inclusion of psychologists and academics - and not only medical staff - in the priority groups), ${ }^{3}$ although the differentiation between prosecutors (priority group), on one hand, and judges and advocates (non-priority groups) is less obvious, unless analysed in the light of the on-going conflict between the judiciary, on one hand, and executive and legislature, on the other. ${ }^{4}$

Finally, one could cite the question of opening or closure of schools. ${ }^{5}$ As it is well known, pupils in Western European countries have been, at least since the $2^{\text {nd }}$ wave of the current pandemic, kept in school either full time (younger pupils) or at least part time in hybrid mode (older pupils). In contrast, pupils in Poland did not see their classrooms between March and mid-June 2020, returning only for the last two weeks, and likewise have been in school only during the first weeks of the school year 2020/2021. One could speculate, on one hand, on the policy reasons behind such a solution - for instance, the overriding need for social integration of

\footnotetext{
${ }^{3}$ Placing academics in a high priority group was the object of controversies. Some argued that persons working at cash registers in shops should be given greater priority. Professor Andrzej Rychard, a sociologist from the Polish Academy of Sciences, expressed the view that "it is a kind of reward for a socially held position, which, by the way, I think is socially acceptable and, in principle, there is nothing wrong with it" (Leszczyński, Rychard 2021). Later on, Professor Rychard retracted on his words (Rychard 2021).

${ }^{4}$ By the time I received this text back from peer review (mid-June 2021), vaccines have become widely available to all adult Polish citizens and residents of Poland, so the entire question of priority groups, so hotly debated at the beginning of the year, now lost any significance.

${ }^{5}$ For an analysis of education in times of pandemic see Indellicato 2020.
} 
migrant communities (in the West) on one hand, and the generally poorer condition of healthcare (in Central Europe). Whereas the reasons for concrete decisions (total school closure in Poland vs. continued opening of schools in Western Europe) could be difficult to reconstruct (due to secrecy of deliberations), the actual impact upon social antagonisms can be ascertained with much greater probability. For instance, concerning the workers vs. capitalists antagonism, the continued opening of schools benefits the capitalist class, as it allows them to exploit the workforce more effectively (without the distraction generated by "teleschooling"). Secondly, concerning the women vs. men antagonism, the continued opening of schools allows women to pursue their professional careers, whereas teleschooling generally impacts women heavier. On the other hand, parents with health vulnerabilities are being exposed to greater risks due to the continued opening of schools, whereas they are offered better protection by total school closure.

To sum up, the critical approach to the corpus iuris pandemici is aimed at revealing, through the analysis of legal material and its social use in practice, whose collective interests are given priority in each and every instance, and how this can be explained in the broader context of the structural conflicts (antagonisms) nurturing society. The importance of comparative legal research as a crucial aid of critical legal theory cannot be underestimated.

\section{COVID AND LEGAL FORM}

Writing back in 2014, Costas Douzinas observed that

As law is disseminated throughout society, its form becomes detailed and inconsistent, its sources multiple and diffused, its aims unclear, unknown or contradictory, its effects unpredictable, variable and uneven. [...] Rule is replaced by regulation, normativity by normalisation, legislation by executive action, principle by discretion, legal personality by administratively assigned roles and competencies. Regulation and normalisation are ubiquitous and invisible, they come from everywhere and nowhere. [...] The law expands inexorably at the price of assuming the characteristics of contemporary society, becoming decentred, fragmented, nebulous. (Douzinas 2014, 194)

In this insightful fragment which, in the second year of the pandemic sounds no less than simply prophetic, Professor Douzinas captured the very essence of the form-substance relationship within the juridical phenomenon. Juridification - the dissemination of legal form - cannot be without effect upon the nature of the legal form as such. In fact, the form vs. content dichotomy applied to law has a very long intellectual history which dates back at least to Aristotle who already contended that generality and vagueness belong to the very nature of law (Leyden 1967, 6). Legal form is, ultimately, that what makes the law what it is, i.e. what imprints upon it legality as such (universal legal form) and what makes it a particular branch or field of law (particular legal form) such as criminal 
law, private law, administrative law, or English law, French law, or Polish law, or various combinations thereof (French administrative law of the $19^{\text {th }}$ century, Polish private law of the socialist period, Italian criminal law of the Fascist era, etc.). Legal form is, as such, a cultural phenomenon and a social construct, hence its borders, both of the universal and particular type, are socially constructed and cannot be logically deduced from any philosophical prima principia. This does not imply that the concept of legal form relies on a logical vicious circle of the type 'law is what lawyers call the law' or 'law is what judges do', which was the weak point of American legal realism. To the contrary, the legal experience of concrete, historically existing and contemporary legal orders provides the parameters for defining legal form (cf. Cotterell 1998, 185-186). The concept is therefore per se rooted historically in, on one hand, the Roman legal experience (as the first appearance of mature legal form) cum the experience of Canon law and the Civilian Tradition that ensued, and the Common Law Tradition, on the other hand. Hence, universal legal form can be described as the formulation of normative precepts in a general and abstract way, combined with a tendency towards systemisation and generalisation (Cotterrell 1998, 186).

For Soviet legal theorists Olimpiad Ioffe and Mikhail Shargorodsky, the form of law was simply the state's rubber-stamping of the will of the ruling class (Joffe, Szargorodski 1963, 40). In this sense, anything that is adopted by the state qua law becomes eo ipso cloaked in legal form (cf. Wróblewski $1976,815)$. Whereas this way of perceiving legal form has certain merit - it allows for a formal distinction between law and non-law - it does not provide a useful blueprint for the study of changes of legal form as such (as legal form is, under this conception, constant). Therefore, it becomes necessary to refer to the distinction made by late Soviet legal theorist, Lev Yavich, who differentiated between internal legal form and external legal form (Yavich 1976, 97-99). It could even be said that Yavich's concept provides the missing link between the classical use of legal form by Pashukanis (2003) and its contemporary use by Duncan Kennedy (1976). For Yavich, the external legal form is the legal form in relation to the actual content (substance), e.g., the economic one. This is the sense of legal form used by Pashukanis and, to an extent, by Ioffe and Shargorodsky. The internal legal form, in turn, is the internal structuring of the law. It is not law-as-form towards a substance which becomes juridified, but law's own form towards the substance of juridical normativity. In other words, the concept of internal legal form allows us to glimpse into law's inner life, whereas the concept of external legal form allows us to observe law's workings vis-à-vis its environment, be it political, economic, cultural, or ideological. Of course, both types of legal form are strictly interconnected, as it is impossible for law to be formless - a modicum of internal legal form is indispensable for the appearance of external legal form, i.e. for law to operate the juridification of certain non-legal relationships (Mańko 2020a, 28). 
The critical study of the legal form of the corpus iuris pandemici can and should approach both dimensions of legal form: external and internal alike. The "covidisation" of law leads to the change of external legal form. Normally, it is characterised by abstraction (Pashukanis 2003, 43-44, 49, 57, 59, 64, 120-121), interchangeability in the guise of conceptual equality, ${ }^{6}$ selectiveness (Collins 2003, 15-16; Mańko 2018, 42-43; Mańko 2020a, 29), arbitrariness (Pashukanis 2003, 60), and programmatic reductionism (Mańko 2020a, 29). To generalise what Hugh Collins wrote concerning contract law, one could say that not only contracts, but also legal form in general 'constructs an image of the human association that reduces its complexity to the elements and trajectories that have significance' for the legal form, and to this end it 'ignores most of the context' of law, and tends to 'displace other normative standards derived from the social context', with the result that it 'reduces the complexity of human association, rendering social relations susceptible to management and reconstruction' (Collins 2003, 15-16). The change brought about by the pandemic to external legal form is that facts which normally would be irrelevant suddenly become crucial. The law's attention is focused on a particular disease - SARS-Cov-2 - which suddenly becomes the legally relevant factor for various juridified relationships. In the most acute way this sudden relevance of COVID-19 for the external legal form can be observed in the concept of "immunity passports," in the requirement of COVID tests prior to boarding a plane or crossing a border, and the like.

But the pandemic affects not only the external, but also the internal legal form, which is even more interesting from the point of view of legal theory. Viewed in the perspective of the longue durée of legal form, the on-going pandemic and its impact upon the juridical can be seen as corroding modern Western legal form, both of its Civil and Common law imprints, as we have known it or, more specifically, as accelerating certain processes of decay that had been noted already earlier. Within the Central European periphery, ${ }^{7}$ the cultural embeddedness of legal form is generally weaker, and the pandemic only exposes how thin this layer of formal, liberal legality has been. A specific feature of the corpus iuris pandemici is the rise of regulation, especially through governmental executive action, at the expense of the traditional form of properly debated parliamentary lex (Griglio 2020; Petrov 2020; Tacik 2021). It seems that this phenomenon has touched Western Europe and Central Europe to a comparable degree, with the

${ }^{6}$ In the sense that legal subjects (personae) and objects (res), as well as legal relationships, both in personam (such as contracts) and in rem (such as ownership), are treated as conceptually equal. Cf. Pashukanis 2003, 14, 113. This becomes especially visible in the very act of exchange: 'In fact, the juridical idea, or the idea of the equivalent, is first clearly delineated and objectively realised at that level of economic development where this form becomes common as equalisation in exchange' (Pashukanis 2003, 170, emphasis added).

${ }^{7}$ On the peripherality of Central Europe see e.g. Kukovec 2014; 2015; Mańko, Škop, Štěpáníková 2016; Mańko 2020e. 
proliferation of emergency decrees here and there alike. Another formal aspect which is patently due to the pandemic is the law's growing instability: what was legal a week ago can become illegal today, and there is no way to predict what kind of measures will be decreed by the Minister of Health or the Government next week. We have not known such a degree of legal instability and unpredictability of law for decades, if not centuries. As Krzysztof Koźmiński and Jan Rudnicki have pointed out:

Instances of the "creation and entry into force of laws in real time" have been observed whereby a high-ranking official during a press conference would orally expound on a previously unknown draft law along with a brief statement of its reasons, and then sign "live" (before journalists, television cameras, and thousands of viewers) such a regulation into law, which is then within hours promulgated in the official journal and enters into force on the same day. This practice - evidently partly justified on account of the COVID pandemic - defies the principles of good legislation [...]. In contrast, the COVID reality has generated a situation where an unexpected decision of a politician becomes a source of universally applicable law, and as such, is immediately enforced. In fact, the familiar timetable of legislative works has become fiction as the consultation process has been replaced by unilateral statements from decision-makers, and media stories (TV programmes, Internet news, or radio broadcasts) have often become a more reliable source of information about binding law than the official Journal of Laws. (Koźmiński, Rudnicki 2020, 108-109)

What is even more perplexing (given the processes of harmonization and unification of law which seemed so ubiquitous!) is the variety of responses to essentially the same phenomena that can be observed in different countries. The contrast between Sweden and the rest of Europe was, perhaps, a first indicator of this kind of differentiation, but the differences in legal responses have only become pronounced since then.

The internal legal form of the corpus iuris pandemici has also been under challenge with regard to its systemic coherence. As Koźmiński and Rudnicki point out:

A symbolic example of the peculiarity of the "COVID legislation" has been the "pandemic special laws", namely legal acts that aspired to the status of "comprehensive regulations" of the entirety of matters affected by the pandemic. Such laws [...], previously unplanned, purported to regulate a wide range of issues of both a public and private character, which were yet to be the subject of the legislator's attention and entirely unregulated. [...] The "COVID special laws" conflated provisions pertaining to the operations of confectioneries and gyms with laws laying down rules governing the organisation of funerals, and political rights [...] with laws angled against speculators. Consequently $[\ldots]$ the special laws were very complex, overly detailed, replete with leges speciales, purported to amend at once dozens or hundreds of acts, and difficult to understand without having recourse to the context of the entire legal system. Therefore, a meaningful perusal of these acts was a challenge both for laymen and experienced lawyers well versed in applying law. Their wording suggests that the drafting process involved persons without any legislative experience or basic awareness of legal terminology. (Koźmiński, Rudnicki 2020, 109-110) 
Undoubtedly, the "COVID special laws", as described by Koźmiński and Rudnicki, can be treated as a symptom of the crisis of the modern legal form and a far-reaching departure from its ideals of systemicity, coherence and elegance, elaborated in the Enlightenment and implemented in the $19^{\text {th }}$ century codifications.

\section{CRITIQUE OF LEGAL IDEOLOGY IN TIMES OF PANDEMIC}

A powerful tool wielded by critical legal theory is the critique of legal ideology (Stambulski 2016; Sabjàn 2019). This is because "[1]aw is first and foremost an ideological practice, a way of understanding the world" (Douzinas 2014, 188). In critical legal theory, ideology is understood as a "universalization project of an ideological intelligentsia that sees itself as acting 'for' a group with interests in conflict with those of other groups" (Kennedy 1997, 39), and at the same time also as "a system [...] of representations (images, myths, ideas or concepts, depending on the case) endowed with a historical existence and role within a given society" (Althusser 2005, 231), and as "a fantasy construction which serves as a support for our 'reality' itself: an 'illusion' which structures our effective, real social relations and thereby masks some insupportable, real, impossible kernel" (Žižek 2008 [1989], 45). As such, ideology "is a structure essential to the historical life of societies" (Althusser 2005, 232), even if it is essentially contested (Kennedy 1997, 42). It plays an important role in upholding the status quo, as it masks and misrepresents 'the Real' of the social antagonism, proposing the fantasy of reality in its place (Marani 2013, 105; Garcia, Aguilar Sanchez 2008).

There can be no doubt that "law is central to ideology" (Douzinas, Gearey $2005,221)$, nonetheless the exact relation between law and ideology is certainly a complex one. On one hand, law simply is subservient to the hegemonic ideology which determines the content of the law (Novkov 2008, 627). In this sense, one can speak about the overdetermination of law by ideology: law, in any of its phenomenological forms (constitution, legislation, regulation, administrative action, adjudication) is overdetermined, as far as its concrete substance is concerned, by a certain ideological vision of how society should be arranged. In this sense, the impact of the pandemic upon law can be analysed by reference to changing ideological inspirations of the COVID measures adopted by various governments. To what extent are they liberal or even libertarian (think of Sweden), or rather conservatively paternalistic and/or social-democratically interventionist (Koźmiński, Rudnicki 2020, 111-112), if not even downright authoritarian (think of excessive lockdowns, imposed in certain countries in an excessive manner, despite their doubtful effectiveness, especially in comparison to other countries in a similar situation).

But the ideological instrumentalisation of law is not the only dimension of the law-ideology nexus. The law itself - the form and content of legal institutions 
- can shape the hegemonic ideology (Novkov 2008, 627), as when people believe that what is prescribed by legal norms is normal and appropriate (Dębska 2015, 251-253). For instance, human subjects interpellated by the law as consumers (homines oeconomici passivi) start feeling more like consumers (economic subjects) than citizens (political subjects) (Hesselink 2007, 323-348; Mańko 2014, 52). The impact of the pandemic upon the ideological outlook of the law has been immense and undoubtedly requires in-depth studies. The legal subject of the corpus iuris pandemici is no longer consumer or citizen, but it is increasingly the patient, interpellated on account of his or her health, presence of $\operatorname{IgG}$ or IgM antibodies in their blood, their prior vaccination or past history of COVID infection. This creates a pretty different ideological outlook of the law: no longer focused on consumption or political participation, but on the purely biopolitical notion of survival and preservation of bare life.

Thirdly, law can possess its own 'guild ideology' or 'professional ideology' of legalism, which aims at justifying the interests of lawyers in society (Halpin 2006, 159). As I have claimed elsewhere, this professional legal ideology - which I propose to call the "juridical ideology" - is no more homogeneous than the external political ideologies that impact upon the law (Mańko 2020a, 39-40). The impact of the pandemic upon the juridical ideology (lawyer's guild ideology) seems to have been, at least for the time being, negligible, although in the long run it cannot be excluded that a prolonged exposure of lawyers towards the extravagancies of pandemic legal form will have some kind of impact upon their own ideological consciousness qua lawyers.

\section{CONCLUSIONS}

The scholarly analysis and critique of law always takes place under circumstances of scarcity of academic resources. At any given moment, the number of academic jurists mastering a given legal system and being capable of analysing and critiquing it at a professional scientific level is limited. The pandemic of COVID-19 only exacerbated this phenomenon, exposing the importance of making methodological and paradigmatic choices. What critical legal theory teaches us is that the choice of method and approach to the analysis and critique of legal materials is not politically neutral (Mańko 2018). Opting for doctrinal legal analysis (so-called 'formal-dogmatic method'), which is the most readily available tool for lawyers, has been the choice of preference for many authors writing on the corpus iuris pandemici. Without negating the importance of maintaining a certain level of coherence of the corpus iuris, including its new pandemic extension - a coherence which cannot be attained without the constant scientific efforts of legal dogmaticians - I would like to make a pleading, in the conclusion of my paper, for more sociologically oriented and politically engaged scholarship in the 
face of the new research topic of "Law \& COVID." The political stakes, including those concerning the future of our polities and the future of law in general, are too high to limit the task of analysis and critique only to the application of traditional, formalist methods focusing on the linguistic and systemic side of the problem. Of course, it is quite important whether a state of emergency should have been introduced, whether a new piece of COVID legislation is compatible with the constitution, or whether a new limitation of human freedoms under COVID regulation can be reconciled with fundamental rights (see e.g., Drinóczi, Bień-Kacała 2020). Nonetheless, answering such questions one cannot but apply proportionality tests and balancing - operations which are, by their very nature, the playground of almost unbound judicial decisionmaking in the field of the political (Kennedy 2011; 2014) and arenas of the most intensive impact of ideology upon law (Mańko 2016). Analysing the choices made by the legislature, executive and judiciary only through the prism of traditional, formalist methods of linguistic and systemic analysis does not have much value. Asking about the political goals and choices behind the solutions adopted by legislators, ministers, civil servants, law enforcement officers, and judges, and about the actual interests impacted by their decisions is much more important and topical in these difficult times. A sociologically oriented critical legal theory can provide the necessary tools for that.

\section{BIBLIOGRAPHY}

Althusser, Louis. 2005. For Marx. London-New York: Verso. https://doi.org/10.3917/dec. althu. 2005.01

Collins, Hugh. 2003. Regulating Contracts. Oxford: Oxford University Press.

Dębska, Hanna. 2015. Władza, symbol, prawo. Społeczne tworzenie Trybunału Konstytucyjnego [Power, Symbol, Law: The Social Construction of the Constitutional Court]. Warszawa: Wydawnictwo Sejmowe.

Douzinas, Costas. 2014. "A Short History of the British Critical Legal Conference or the Responsibility of the Critic." Law and Critique 25(2): 187-198. https://doi.org/10.1007/ s10978-014-9133-9

Douzinas, Costas. Adam Gearey. 2005. Critical Jurisprudence: The Political Philosophy of Justice. Oxford: Hart Publishing.

Drinóczi, Tímea. Agnieszka Bień-Kacała. 2020. "COVID-19 in Hungary and Poland: extraordinary situation and illiberal constitutionalism". Theory and Practice of Legislation 8(1-2): 171-192. https://doi.org/10.1080/20508840.2020.1782109

García, George I. Carlos G. Aguilar Sanchez. 2008. "Psychoanalysis and politics: The theory of ideology." International Journal of Žižek Studies 2(3).

Griglio, Elena. 2020. "Parliamentary oversight under the COVID-19 emergency: striving against executive dominance". Theory and Practice of Legislation 8(1-2): 49-70. https://doi.org/10.1 080/20508840.2020.1789935

Halpin, Andrew. 2006. “Ideology and Law.” Journal of Political Ideologies 11(2): 153-168. https:// doi.org/10.1080/13569310600687932 
Hesselink, Martijn. 2007. "European Contract Law: A Matter of Consumer Protection, Citizenship, or Justice?" European Review of Private Law 15(3): 323-348.

Indellicato, Rosa. 2020. "Human rights and the educational role of technologies during the COVID-19 period." Journal of Modern Science 45(2): 63-76. https://oi.org/10.13166/ $\mathrm{jms} / 131238$

Joffe, Olimpiad. Michaił Szargorodski. 1963. Zagadnienia teorii prawa [Questions of Legal Theory]. Warszawa: PWN.

Kennedy, Duncan. 1976. "Form and Substance in Private Law Adjudication." Harvard Law Review 89: 1685-1778. https://doi.org/10.2307/1340104

Kennedy, Duncan. 1997. A critique of adjudication \{fin de siècle\}. Cambridge: Harvard University Press.

Koźmiński, Krzysztof. Jan Rudnicki. "The COVID Crisis as a Sample Tube with Contemporary Legal Phenomena." Central European Journal of Comparative Law 1(2): 105-122. https://doi. org/10.47078/2020.2.105-121

Kukovec, Damjan. 2014. "Hierarchies as Law." Columbia Journal of European Law 21(1): 131193. https://doi.org/10.1111/eulj.12113

Kukovec, Damjan. 2015. "Law and the Periphery." European Law Journal 21(3): 406-428. https:// doi.org/10.1111/eulj.12113

Lara Ortiz, María Lidón. 2020. "Restrictions on freedom of movement and residence in the European Union due to COVID-19." Journal of Modern Science 45(2): 105-120. https://doi. org/10.13166/jms/130707

Leszczyński, Adam. Andrzej Rychard. 2021. “Szczepienia akademików to „nagroda za pozycję społeczną?” Prof. Rychard: Kolejność jest sprawiedliwa.” Oko Press, March 8, 2021. https:// oko.press/szczepienia-akademikow-prof-rychard-kolejnosc-jest-sprawiedliwa/ [Accessed: 10 May 2021].

Leyden, Wolfgang von. 1967. "Aristotle and the Concept of Law." Philosophy: The Journal of the Royal Institute of Philosophy 42: 1-19. https://doi.org/10.1017/S0031819100000826

Mańko, Rafał. 2014. "Koncepcja interpelacji ideologicznej a krytyczny dyskurs o prawie" [The Notion of Ideological Interpellation and Critical Discourse on Law]. Archiwum Filozofii Prawa i Filozofii Społecznej 1: 41-54.

Mańko, Rafał. 2016. "Ideology and Legal Intepretation: Some Theoretical Considerations." In Constitutional Values in Contemporary Legal Space. 117-126. Edited by Kalvis Torgāns. Riga: LU Akadēmiskais apgāds.

Mańko, Rafał. 2018. "Nauki prawne wobec problemu polityczności: zagadnienia wybrane z perspektywy jurysprudencji krytycznej" [Legal sciences towards the problem of the political: selected issues from the perspective of critical jurisprudence]. Archiwum Filozofii Prawa i Filozofii Spolecznej 3: 38-50.

Mańko, Rafał. 2020a. "Legal Form, Ideology and the Political." In Legal Scholarship and the Political: In Search of a New Paradigm. 17-44. Edited by Adam Sulikowski, Rafał Mańko, Jakub Łakomy. Warszawa: C.H. Beck.

Mańko, Rafał. 2020b. "Legislation and the Political: Towards Critical Legisprudence." In New Perspectives on Legislation: A Comparative Approach. 11-36. Edited by Paweł Chmielnicki, Adam Sulikowski. Berlin: Peter Lang.

Mańko, Rafał. 2020c. "The Political as an Analytical Category in the Critical Study of Case Law (Theoretical Model and Case Study)." Critique of Law/Krytyka Prawa 12(3): 90-108. https:// doi.org/10.7206/kp.2080-1084.397

Mańko, Rafał. 2020d. "Dimensions of the Political in Adjudication: A Case Study." Acta Universitatis Lodziensis. Folia Iuridica 92: 5-16. https://doi.org/10.18778/0208-6069.92.01 
Mańko, Rafał. 2020e. "Being Central European, or some reflections on law, double peripherality and the political in times of transformation." In Central and Eastern Europe as a Double Periphery? 17-44. Edited by Tomáš Gábriš, Ján Sombati. Berlin: Peter Lang Verlag.

Mańko, Rafał. 2021. "Judicial Decision-Making, Ideology, and the Political: Towards an Agonistic Theory of Adjudication." Law and Critique. https://doi.org/10.1007/s10978-021-09288-w

Mańko, Rafał. Jakub Łakomy. 2018. "In search for the ontological presuppositions of critical jurisprudence." Critique of Law/Krytyka Prawa 10(2): 469-486.

Mańko, Rafał, Martin Škop. Markéta Štěpáníková. 2016. "Carving out Central Europe as a Space of Legal Culture: A Way out of Peripherality?" Wroclaw Review of Law, Administration and Economics 6(2): 3-28. https://doi.org/10.1515/wrlae-2018-0002

Marrani, David. 2013. "Althusser in 'Avatar'." In Althusser and Law. Edited by Laurent de Sutter. Abingdon: Routledge.

Mouffe, Chantal. 2013. Agonistics: Thinking the World Politically. London: Verso.

Novkov, Julie. 2008. "Law and Political Ideologies". In The Oxford Handbook of Law and Poltitics. Edited by Gregory A. Caldeira, R. Daniel Kelemen, Keith E. Whittington. Oxford: Oxford University Press. https://doi.org/10.1093/oxfordhb/9780199208425.003.0036

Petrov, Jan. 2020. "The COVID-19 emergency in the age of executive aggrandizement: what role for legislative and judicial checks?". Theory and Practice of Legislation 8(1-2): 71-92. https:// doi.org/10.1080/20508840.2020.1788232

Rychard, Andrzej. "Rychard: palnąłem o szczepieniu jako nagrodzie dla akademików. Może tylko kryterium wieku?" Oko Press, March 9, 2021. https://oko.press/rychard-palnalemo-szczepieniu-jako-nagrodzie-dla-akademikow-moze-tylko-kryterium-wieku/ [Accessed: 10 May 2021].

Sabjàn, Nikolas. 2019. "Critical Approaches to Law and Ideology: Taking the Ideological Critique of the Rule of Law Seriously." In Dny práva 2018. Days of law 2018. Ćást VIII. Návrat k nedemokratickým režimům ve střední Evropě?, Law and Critique in Central Europe. 127149. Edited by Ladislav Vyhnánek, Zuzana Vikarská, Miloš Večeřa, Terezie Smejkalová, Jiř́ Valdhans. Brno: MUNI Press.

Stambulski, Michał. 2016. "The Critique of Ideological Legal Reason." Wroclaw Review of Law, Administration and Economics 5(1): 48-60. https://doi.org/10.1515/wrlae-2015-0022

Šimanskienè, Ligita. Jurgita Paužuolienè. Arnas Staškevičius. 2020. "Changes in society during COVID-19 pandemic: from the point of view of health care workers." Journal of Modern Science 45(2): 93-104. https://doi.org/10.13166/jms/130702

Tacik, Przemysław. 2021. "The Blizzard of the World: COVID-19 and the Last Say of the State of Exception." Acta Universitatis Lodziensis. Folia Iuridica 97: 5-13.

Wróblewski, Jerzy. 1976. "State and Law in Marxist Theory of State and Law." Wayne Law Review 22: 815-739.

Yavich, Lev Samoilovich. 1976. Obshchaya teoriya prava [General Theory of Law]. Leningrad: Izdatel'stvo Leningradoskogo Universiteta.

Žižek, Slavoj. 2008 [1989]. The sublime object of ideology. London: Verso. 